\title{
The Role of Local Government, Religious and Community Figures, In Conjunction With the Security Forces (Polri) In Returning A Harmonic Life Post Conflict As Ethnic In Sambas Regency
}

\author{
Setyo Utomo ${ }^{1}$ \\ Faculty of Law of Panca Bhakti Unviersity, Pontianak, Indonesia ${ }^{1}$ \\ setyoutomodw@yahoo.com ${ }^{1}$
}

\section{Keywords :}

Human Rights, Conflict,

Sambas Regency, Ethnicity, Harmony

\begin{abstract}
Humans as God's creatures are given freedom of human rights from birth. As a citizen, it is necessary that the State shall be obliged to protect the freedom of the rights of its citizens. However can't be denied the freedom of human rights between human beings with each other in fact lead to differences in interests that led to the emergence of conflicts that often lead to the occurrence of fatalities and loss of property. Whereas one of the citizens' rights is free to live anywhere within a territory of the State. Likewise with citizens of Indonesia, in the Constitution of the State has guaranteed the freedom to reside within the territory of the Unitary State of the Republic of Indonesia. Based on the experience of conflicts in the country, with the postconflict handling of those who had previously conflicted it can be reunited in living a harmonious life, but unlike the conflict that occurred in Sambas Regency in 1999 between ethnic Malays and Madurese which has been over the years and with post-conflict efforts that have been done until now people in Sambas district have not been able to accept the presence of Madurese in Sambas Regency.
\end{abstract}

\section{INTRODUCTION}

To quote the opinion that Thomas Hobbes once expressed, namely: "Homo Homini Lupus Homo Homini Socius" which means that man is not as a wolf to other human beings but rather that man is a social creature. This means that in this life man in fulfilling his needs can not live alone without the presence of other human beings. In social life in general, all human beings on earth want interaction between people should be peaceful, but considering the different characters between people with each other so as not to close the possibility of causing differences in interests between humans who culminating in a conflict. In the event of a conflict, attempts to dampen or end the conflict itself depend on the magnitude of the potential for conflict to affect the short duration or duration of resolution of a conflict.

Indonesia is a plural country, in the sense that its society consists of various tribes, religions, races and classes. Differences in views and objectives are often seen as problems that can only be solved if we all have the same intentions, or when a view is stronger than other views can be sought to resolve. So 
with the settlement of the differences of interest that often cause social friction (conflict) in society remain integrated in the framework of the Unitary State of the Republic of Indonesia.

In general, conflict is caused by differences of opinion, thought, speech, and deed. A difficult basic attitude and not wanting to accept and appreciate such differences will change a person's conflicted character. People like this will create small and simple problems as an excuse to create conflict. Conflict as a conduit of continuous concealment of feelings that forces a person to behave and do something contrary to others. A strong desire of ambition even leads to conflict between individuals, while a strong emotional drive to blame others will cause a person to conflict with others.

Conflict can be interpreted as a relationship between two or more parties (individuals or groups) who have or feel to have objectives that are not in line (Gibson and Mitchell, 1981). This understanding must be distinguished from violence, which includes actions, sayings, attitudes or various structures and systems that cause physical, mental, social and environmental damage and / or prevent a person from reaching his or her full potential (Fisher et.al, 2001).

As stated in the Constitution Year 1945 of the State of the Republic of Indonesia, the objective of the establishment of the Indonesian nation is to create a just, prosperous and prosperous society within the Unitary State of the Republic of Indonesia. Thus it is the responsibility and obligation of every citizen to participate in realizing security and welfare throughout the territory of Indonesia and is entitled to live freely and independently in every territory of the Unitary State of the Republic of Indonesia.

The existence of the Constitution Year 1945 of the State of the Republic of Indonesia and Act Number 39 Year 1999 on Human Rights provides a guarantee of protection for various ethnic groups in Indonesia to live peacefully throughout the territory of the Unitary State of the Republic of Indonesia. A government that runs a State is given a bond to make people's aspirations a consideration in the formation of a policy (Ishaq, 2012). Public service is a government institution bond that is responsible for providing various needs of the people. The provision of security / security is an essential part of a government's duty. When the time comes when the obligation is not applied, or even disalagunakan by the government, then the conflict broke out.

Recognizing the conditions and challenges in the life of the nation and democratic country, on May 10, 2012 the Government has issued Act Number 7 Year 2012 on Handling of Social Conflict. The law has also defined the scope of conflict management including conflict prevention, and post-conflict recovery. The prevention of conflicts involves, among others, through the maintenance of peaceful conditions within communities, developing peaceful dispute settlements, reducing potential conflicts, and building early warning systems (Bisri, 1988). The handling of conflicts in the event of a conflict, carried out through efforts to stop physical violence, the determination of the status of conflict, emergency measures of rescue and protection of victims, and / or mobilization and use of force of the TNI. Furthermore, in the post-conflict phase, the Government and the Regional Government are obliged to undertake a planned, integrated, sustainable, and measured Post-Conflict Response effort through reconciliation, rehabilitation and reconstruction efforts. Act Number 7 Year 2012 on the Handling of Social Conflict also regulates community participation, and funding conflict management. Started from the events of ethnic conflict that had occurred in Sambas Regency some time ago that caused a lot of casualties and property, until now leaving a situation where local people, the ethnic Malay can not recognize the presence of our relatives who come from ethnic immigrants, the ethnic Madurese to be able to reside in Sambas Regency as before the conflict. According to the authors, this is what distinguishes conflicts that have occurred in Sambas district with conflicts that have occurred in other areas, where with the efforts taken by related agencies after the occurrence of life conflict among the parties in conflict can be re-established. With respect to human rights to live peacefully and to live anywhere within the territory of the Unitary State of the Republic of Indonesia, it is appropriate that the impacts left behind as a result of past ethnic conflicts can be overcome to restore the once harmonic state of life. 


\section{PROBLEMS}

Based on the above description of the introduction, then the formulation of the problems posed by the author are: How is the role of local government, religious and community figur, in conjunction with the security forces (Polri) infrastructure returning a harmonic life post conflict as ethnic in Sambas Regency?

\section{DISCUSSIONS}

\section{A. Understanding and Forms of Conflict 1. Definition of Conflict}

Conflict is a social phenomenon that is always present in every society in every period of time. Conflict is an integral part of community life because conflict is one product of social relations (social relations). Society consists of a large number of social relationships, so there is always a conflict between citizens involved in social relationships. Conflict is a conflict vocabulary in English, which describes situations and conditions in which people are experiencing factual disputes and disputes that exist only in their perceptions. Conflict refers to disputes whose parties have been or have not been identified or can be clearly identified. A person may experience conflict with people in his environment or social and economic conditions that are inconsistent with his personal principles, so he or she experiences a conflict with his social environment. conflict can be divided into two namely:

1) Individu conflict is a conflict that occurs between two people who do not involve their respective groups; while

2) Group conflict is conflict between two or more groups.

The conflict arose from the pluralistic condition of the society structure, the conflict is a frequent phenomenon, the conflict is often caused by misunderstanding one of the most prominent assumptions, misunderstanding and trying to clarify not only the moral orientation of the conflicting parties but also their actual expectations others that have been misconstrued.

Experts' opinions on the Conflict are as follows:

1) According to Hendropuspito, conflicts can be defined as a social process in which two people or groups attempt to remove others by destroying or destroying them (Hendropuspito, 1989).

2) According to Kartini Kartono, in the life of a very complex society with various problems, will bring open conflicts. The word conflict can be translated as opposition, antagonistic interactions, clashes between kinds of understandings, disagreements, disputes, fights, resistance with weapons and war.

3) According to Abu Ahmadi, conflict is a deliberate attempt to oppose, resist or impose the will of others. Usually the conflict arises from the existence of conflicting interests, especially economic interests, and often also because of seizure of positions and power (Ahmadi, 1975).

4) Maswadi Rauf. The term conflict comes from the word "confligere" which means to hit each other. Conflict can be defined as a social process in which two people or groups attempt to remove others by destroying or destroying them (Rauf, 2001).

5) According to Doyle Paul Johnson, conflict is as one form of interaction. Conflict is closely intertwined with processes that unite in social life, and not just opposed to unity.

6) According to Kusnadi, seen from the process, the conflict was at least two stages;

a) Stages of disorganization are many misunderstandings, norms begin to be disobeyed, members of many deviant, weak sanctions.

b) Degenerated stage that arises emotion (hatred), like angry (want to destroy), want to attack.

Kusnadi also said that the factors causing the conflict include:

a) There are differences in various aspects;

b) There is a conflict of interest; and

c) The existence of uneven social change. 
From the various opinions on the conflict mentioned above it can be concluded that the conflict is a conflict, disputes, disputes and differences of opinion between two people or groups that occur because of social interaction, thus causing the other party trying to get rid of the other party.

\section{Conflict Forms}

In a line, various conflicts in society can be classified into the following forms of conflict:

a. Based on the nature

Based on the nature, conflicts can be divided into destructive and constructive conflict.

1) Destructive Conflict. Is a conflict that arises because of feelings of displeasure, hatred and resentment of a person or group against another party. In this conflict there are physical clashes resulting in loss of life and property. For example conflict Poso, Ambon, Kupang, Sambas, and so forth.

2) Constructive Conflict. Is a functional conflict, this conflict arises because of differences of opinion from groups in the face of a problem. This conflict will result in a consensus of these opinions and result in an improvement. For example dissent in an organization.

b. Based on the Position of Conflicting Persons

1) Vertical Conflict. Is a conflict between components of society within a structure that has a hierarchy. For example, conflicts that occur between superiors with subordinates in an office.

2) Horizontal Conflict. Is a conflict that occurs between individuals or groups who have a relatively equal position. Examples are conflicts that occur between mass organizations.

3) Diagonal Conflict. It is a conflict that occurs because of unfair allocation of resources throughout the organization resulting in extreme conflicts. For example the conflict that occurred in Aceh.

c. Based on the nature of the perpetrators in conflict

1) Open Conflict. It is a conflict known to all. For example the Palestinian conflict with Israel.

2) Closed Conflict. It is a conflict known only to the people or groups involved in the conflict.

d. Based on the Concentration of Human Activities in Society

1) Social conflict. Is a conflict that occurs due to differences in social interests of the parties in conflict. These social conflicts can be divided into vertical social conflicts and horizontal social conflicts. This conflict often occurs because of the provocation of irresponsible people.

2) Vertical Social Conflict, the conflict between the people and the state. For example the mass anger that culminated in the Trisakti event (May 1998).

3) Horizontal Social Conflict, ie conflict between ethnic, ethnic, class, or among community groups. for example the conflict that occurred in Ambon.

4) Political Conflict. Is a conflict that occurs because of differences in interests related to power. Examples are conflicts that occur between supporters of a political party.

5) Economic Conflict. Is a conflict due to the seizure of economic resources from the parties in conflict. For example conflict between entrepreneurs when conducting a tender.

6) Cultural Conflict. Is a conflict that occurs because of differences in cultural interests of the parties in conflict. Examples are differences of opinion among groups in interpreting the bill (draft law) antipornography and porno action.

7) Ideological Conflict. Conflict due to differences in understanding that is believed by a person or group of people. for example the conflict that occurred during the G $30 \mathrm{~S} / \mathrm{PKI}$.

\section{B. Conflict Countermeasures}

\section{The Role Of Local Government In Preventing And Overcoming Conflict}

With the issuance of Presidential Instruction no. 2 of 2013 on the Handling of Domestic Security Disorders in January 2013, there can be no doubts of action, delay in acts, delay in overcoming them and unable to prevent something that can be prevented, and no longer to deal communal conflicts, violence and terrorism in a way complete. Based on Presidential Instruction No. 2 of 2013 on the 
Handling of Domestic Security Disorder is affirmed the role of governors, regents, mayors as head of an integrated team at the regional level. Namely: (1) Developing an integrated national action plan, (2) Coordinating the implementation of improving the effectiveness of the handling of security disturbances in its area; (3) Immediately provide explanations to the public about the occurrence of security disturbances in their areas as a result of social conflict and terrorism and the development of their handling, and (4) Report their implementation to the Coordinating Minister for Political, Legal and Security Affairs. In this regard, to maintain the stability of security in the region, the Ministry of Home Affairs has made a policy, among others: Joint Regulation of Minister of Religious Affairs and Minister of Home Affairs. 9 Year 2006 - No. 8 of 2006 on Guidelines for Implementation of Duties of Head of Region in Maintaining Religious Harmony, Empowering Forum of Religious Harmony and Establishment of House of Worship. Permendagri No. 11 Year 2006 concerning Kominda as amended to Permendagri No. 16 of 2011. In addition, Minister of Home Affairs Regulations No. 12 Year 2006 on Community Early Precautions in the Region. Minister of Home Affairs Regulations No. 34 Year 2006 on Guidelines for the Implementation of National Renewal in the Region, and Minister of Home Affairs Regulations No. 61 Year 2011 on Guidelines for Monitoring, Reporting and Evaluation of Political Developments in the regions.

As mandated by Act No. 7 Year 2012 on the Handling of Social Conflict: (1) That the Government and Local Government shall reduce the potential for social conflict in society (Article 9). (2) The Government and Local Government shall establish an early warning system (Article 10). (3) In the state of the district-level conflict situation, the bupati / mayor is responsible for handling district / city conflict (Article 23 paragraph 1). (4) In the state of a provincial conflict, the governor is responsible for the handling of the provincial conflict (Article 24 paragraph 1). (5) Under certain circumstances aids the use and direction of the TNI (Article 33). (6) Membership of task force (task force). The provincial social conflict (Article 48), Regency/City (Article 47) consists of elements of local government and community. The elements of regional government consist of: (a) Governors, Regents / Mayors; (b) Chairman of Regional House of Representatives Provincial, Regency / Municipal DPRD; (c) Government agencies and / or SKPD as required; (d) Kalpolda, Kapolres; (e) Commander, Kodim / Commander of TNI elements, and (e) Kejati, Kejari; (7) Community elements consist of: religious figures, customary figures, community figures, peace activists and representatives of conflicting parties.

\section{The Roles of Religious and Community Figures in Preventing and Overcoming Conflict}

The active participation of religious leaders (who in Islam such as ulama, kiay, ustadz and the like) are highly desirable, as they are informal leaders who are often more respected, more obedient and more beloved than formal leaders in Indonesian society, the world at large. That is because there are two main aspects, namely: First, the intellectual aspect in the field of religion that is behind their more ability. Secondly, the functional aspects related to their immediate real role in the community, such as among others;

1) Leading the implementation of religious ritual (ritus) ceremonies.

2) Being a questioning place for the community in many ways, such as family life, security and treatment.

3) Being role models in social behavior (qudwah hasanah).

Therefore, the religious leaders, especially the Islamic scholars, can play a part in moving the dynamics of the nation, such as preventing and resolving conflicts, especially the horizontal conflicts of the SARA nuances. Therefore, they can be appointed in three performance roles as follows:

1) As the spiritual guide of the nation.

2) As a container and formulation of community aspirations.

3) As a leader and steering community movement. 


\section{The Efforts of Security (Police) In Overcoming And Preventing Conflict}

From the conflict issues that exist in various aspects of social life, if not can be anticipated early in turn can develop into a real disruption resulting in harm to society, nation and state in the form of security or crime disruption, decreasing the confidence of the people of Indonesia and the international world against the Government RI as well as the weakening of the unity and unity of the nation that affect the sustainability of national development and the unity of NKRI.

How the Police effort in tackling the conflict, first need to be described in general about the perception of the Police after the amendment of the 1945 Constitution of the Republic of Indonesia which is where the Police in formulating the concept and policy and the security strategy of the state remain consistent to the constitutional basis by referring to the fourth paragraph of the preamble of the 1945 Constitution and chapter XII article 30 on state defense and security whose operational implementation is regulated normatively in the Police Act Number 2 Year 2002 with various implementing regulations.

In the Police Act Number. 2 Year 2002, the main task of the Police (Article 13) is further detailed in the formulation of tasks (Article 14) which includes pre-emptive, preventive, non-judicial and repressive judicial duties. At every level of the task, coordination, cooperation, assistance and participation of various components of the nation, institutions and society are always needed. Without cooperation with other components, especially with the TNI, local government and other agencies and the community, the efforts to maintain internal security will not be free from security threats.

Observing the source of threats in the form of potential disruption that settles in various aspects of community life that can at any time be correlated and even triggered into conflict, then the Police effort in conflict management with measures of prevention and action. Almost every day we watch, read, and perhaps even experience conflict situations and consequences for ourselves, groups, or organizations. Conflict is a natural and natural conflict between individuals or groups as a result or a result of differences in attitudes, beliefs, values, or needs.

Conflict does not always mean negative, if prevented through effective management can be a healthy or positive conflict, can generate growth, innovation new insights, and alternative management options. But the problem arises when the conflict is accompanied by violence that clearly violates the rule of law and human rights, whose intensity is increasing and causing the suffering of society, even threatening the integrity of the nation and state of RI.

By looking at individual traits, community groups and conflict-causing factors, the efforts that can be done by the Police to prevent the occurrence of conflict are through the implementation of the task of Police that is pre-emptive and preventive in accordance with the duties, functions and role of the Police who prioritize in dampening turmoil so as not to extend to other problems that lead to conflict becomes complex and complicated, while functioning functionally and proportionately through the following prevention efforts.

Activity begins with intelligence activities, to identify and assess potential disruptions that settle on various aspects of community life as described above, followed by activity conditions to prevent potential interference is not correlated and triggered into a real nuisance. In addition, mapping of conflict-prone areas across Indonesia can be mapped.

The next step is through operational strategy by implementing community policing strategy which in essence builds community partnership and police to jointly solve the problems encountered. Efforts to prevent situations or locations that allow the occurrence of conflicts such as interference thresholds implemented with preventive patterns and strategies include turjawali (arrangement, guarding, guarding, and patrol) and coaching conducted by all actors associated with the situation encountered.

In this preventive effort, the Police can not directly address the source of the problem due to the 
competence of relevant technical institutions and the community. In this case the Police apply the principle of participation and develop cross-sectoral work patterns. Coping with detection and preemptive patterns and strategies through engineering, coaching by all elements together with the community and country components through partnerships.

From the view of the Police, security has been well underway based on the normative provisions of Act Number 2 Year 2002 (Chapter VII Help, Relationships and Cooperation Articles 41 and 42). The coordination between the TNI, the Regional Government and the Police and other relevant agencies is harmonious, although it is recognized that the "rules of involvement" of other components at every level of Police duty still need to be confirmed and perfected. Coordination and synergy of activities in the field is strengthened by informal approaches and partnerships.

Against the implementation of conflict action that leads to the occurrence of riots and anarchist actions, the Police still refers to the level of duty as described above, of course, with a repressive strategy for preventive action, namely taking decisive action based on the rule of law applicable with respect to human rights in order to prevent widespread conflict. The steps taken include:

1) Localize the widespread conflict with a balanced mobilization of forces, empowering the leaders of both sides, in coordination with other security forces and local authorities.

2) b. Law enforcement by identifying conflict initiators, arresting perpetrators, and conducting investigations.

3) c. Police restricted non-pro-judicial actions include mass control, mass dissolution, reconciliation of conflict parties, restoration of disturbed public order.

\section{CONCLUSIONS}

As for the conclusions that the author can put forward in this article is as follows:

1) As local authorities should still do their best to ensure that the post-conflict conditions can restore the living conditions as they were before the conflict, namely the realization of the wishes of the victims of the conflict in this case the Madurese to be able to go back to life in the region of Sambas Regency.

2) The role of religious leaders and community leaders in providing understanding and awareness of the importance of tolerance in common life should be maximized not only in the community at the forefront but also throughout the grass root.

3) For the security side (Polri), besides applying community policing strategy, it is hoped to apply more optimal pre-emptive and preventive efforts and ultimately a strict repressive effort if the preemptive and preventive efforts are still causing insecurity in society.

\section{REFERENCES}

Abu Ahmadi, Introduction to Sociology, 1975, Ramadhani, Surakarta.

Doyle Paul Johnson, Classical And Modern Sociology Theory, 1986, Gramedia Pustaka Utama, Jakarta.

Gibson and Mitchell, Introduction to Group Counseling, Rineka Cipta, 1981, Jakarta.

Hendropuspito, Systematic Sociology, 1989, Kanisius, Yogyakarta.

Ishaq, Fundamentals of Legal Science, 2012, Sinar Grafika, Jakarta.

Ilham Bisri, Indonesian Legal System, 1998, Grafindo Persada, Jakarta.

Kusnadi, Fisherman Sociology Conflict (Poverty and Natural Resources Seize), 2002, LKI, Yogyakarta. 
Maswadi Rauf, Political Consensus A Theoretical Appraisal, 2002, Directorate General of Higher Education Depdikbud, Jakarta.

Simon Fisher, et.al, Managing Conflict, Skills and Strategies for Action, 2001, The British Council.

The Constitution of the Year 1945 State of the Republic of Indonesia.

Act Number 39 Year 1999 on Human Rights.

Act Number 2 of 2002 on the Police of the Republic of Indonesia.

Act Number 7 Year 2012 on Handling of Social Conflict.

Presidential Instruction No. 2 of 2013 on Handling of Domestic Security Disorders. 